Tropical Journal of Pharmaceutical Research January 2016; 15 (1): 157-165

ISSN: 1596-5996 (print); 1596-9827 (electronic) (c) Pharmacotherapy Group, Faculty of Pharmacy, University of Benin, Benin City, 300001 Nigeria.

All rights reserved.

Available online at http://www.tjpr.org

Original Research Article

http://dx.doi.org/10.4314/tjpr.v15i1.22

\title{
Simultaneous Determination of Two Isomers of Asarone in Piper sarmentosum Roxburgh (Piperaceae) Extracts using Different Chromatographic Columns
}

\author{
Mohd Shahrul Ridzuan Hamil' ${ }^{1}$, Abdul Hakeem Memon ${ }^{1}$, Amin Malik Shah Abdul \\ Majid $^{2}$ and Zhari Ismail ${ }^{1 *}$ \\ ${ }^{1}$ Department of Pharmaceutical Chemistry, ${ }^{2}$ Department of Pharmacology, School of Pharmaceutical Sciences, Universiti Sains \\ Malaysia, Minden 11800, Pulau Pinang, Malaysia
}

${ }^{*}$ For correspondence: Email: ismailzhari@gmail.com; Tel: +604653888 ext 4222; Fax: +604-6570017

\begin{abstract}
Purpose: To develop a rapid and reliable reverse phase high performance liquid chromatography $(R P$ HPLC) method to quantify the two isomers of asarones in $P$. sarmentosum extracts using two different columns under similar analytical conditions.

Methods: Two isomers, $\alpha$ - and $\beta$-asarone, were analyzed using two types of $C$ - 18 columns with $0.1 \%$ orthophosphoric acid: acetonitrile: methanol (50: 40: 10) as mobile phase. The developed method was applied to determine the contents of $\alpha$ - and $\beta$-asarone in extracts of different parts of $P$. sarmentosum. Results: Column A retention times for the elution of $\alpha$ - and $\beta$-asarone were $11.890 \pm 0.008$ and $10.80 \pm$ $0.004 \mathrm{~min}$, respectively, and were significantly shorter than those of column $B(15.110 \pm 0.024$ and $13.290 \pm 0.018$, respectively, $p<0.001)$. Column $B$ showed better resolution $(1.82 \pm 0.025$ of the isomers than column $A(1.10 \pm 0.01, p<0.001)$. Both columns showed comparable sensitivity, precision and selectivity of the compounds investigated. $\alpha$-Asarone level was in the range $0.36-5.14 \%$ in ethanol and $50 \%$ ethanol extracts, but absent in all water extracts. $\beta$-Asarone occurred in the range of $0.01-0.15 \%$ in ethanol and $50 \%$ ethanol extracts but was absent in all water extracts of $P$. sarmentosum.

Conclusion: The results indicate that the developed method is a suitable quality assurance method for determining $\alpha$ - and $\beta$-asarone isomers in herbal extracts and food preparations.
\end{abstract}

Keywords: $\alpha$ - Asarone, Isomers, Piper sarmentosum, Herbal extracts, Retention time

Tropical Journal of Pharmaceutical Research is indexed by Science Citation Index (SciSearch), Scopus, International Pharmaceutical Abstract, Chemical Abstracts, Embase, Index Copernicus, EBSCO, African Index Medicus, JournalSeek, Journal Citation Reports/Science Edition, Directory of Open Access Journals (DOAJ), African Journal Online, Bioline International, Open-J-Gate and Pharmacy Abstracts

\section{INTRODUCTION}

Piper sarmentosum Roxburgh (family: Piperaceae) is a herbaceous shrub, and is most widely distributed in Southeast Asia including Malaysia, Cambodia, Laos, Philippines, Myanmar, Thailand, Vietnam and China [1]. The plant has been investigated for a number of pharmacological activities such as hypoglycemic [2], anti-amoebic [3], antibacterial [4], neuromuscular blocking [5], anti-malarial [6], antioxidant [7], anti-tuberculosis [8], anticancer [9] and anti-angiogenic activity [10].

The chemical constituents identified from the plant include (2E, 4E)-N-isobutyldecadienamide, $\mathrm{N}$-(2-phenylpropanoyl) pyrrole, sarmentine, sarmentosine, 1-(3,4-methylenedioxyphenyl)(1E)-tetradecane, 1-allyl-2,6-demethoxy-3,4methylenedioxybenzene, asaricin, $\alpha$-asarone, $y$ - 
asarone, hydrocinnamic, oxalic acids, sitosterol and naringenin [11,12]. Asarones are mostly found in isomers i.e. cis- and trans-forms. The trans-asarone or $\alpha$-asarone chemically known as (E)-1,2,4-trimethoxy-5-(prop-1-en-1-yl) benzene while cis-asarone or $\beta$-asarone known as (Z)1,2,4-trimethoxy-5-(prop-1-en-1-yl)benzene.

Apart from showing biological activities, i.e. anthelmintic, pesticidal and neuroprotective [13, 14], both $\alpha$ - and $\beta$-asarones are also known as carcinogenic and genotoxic compounds $[15,16]$. $\beta$-asarone possesses toxic and sterilizing effects [17] whereas $\alpha$-asarone showed greater cytotoxic effect [18].

In food and herbal industries it is required that the quantity of asarones be limited to ascertain the products safety [19-21]. Therefore, analysis of these asarone isomers in $P$. sarmentosum is important for its quality control in herbal remedy preparation.

This study was conducted in order to develop and validate a simple and robust RP-HPLC method for the quantification of $\alpha$ - and $\beta$ asarones in different extracts of $P$. sarmentosum without using large quantity of organic solvents and special stationary phase or modifiers for the separation of asarone isomers.

\section{EXPERIMENTAL}

\section{Preparation of raw material}

$P$. sarmentosum plant was collected from Batu Gajah, Malaysia. The plant samples were identified by Dr. Rahmad Zakaria from School of Biological Sciences, Universiti Sains Malaysia and the specimen vouchers were deposited at School of Biological Sciences, Universiti Sains Malaysia with voucher number USM/Herbarium/11481. The plant samples which were divided into four different parts (leaf, stem, root and fruit) were ground into powder form using an electric grinder SM-100 (Retsch, Germany).

\section{Chemicals and reagents}

All solvents used were of HPLC grade and were acquired from Merck Sdn. Bhd. (Selangor, Malaysia). Authentic $\alpha$ - and $\beta$-asarones were obtained from Sigma-Aldrich (M) Sdn. Bhd (Kuala Lumpur, Malaysia). Two C-18 columns $(250 \times 4.6 \mathrm{~mm}, 5 \mu \mathrm{m})$; (A) ZORBAX Eclipse Plus Phenyl-Hexyl and (B) ZORBAX Eclipse Plus were purchased from Agilent Technologies (USA).

\section{Preparation of extracts}

All extracts were prepared by maceration of powdered material with $99 \%$ ethanol, $50 \%$ ethanol and water solvents at $60{ }^{\circ} \mathrm{C}$ for $48 \mathrm{~h}$. All extracts were filtered; the solvent was evaporated to dryness using rotary evaporator R100 (Buchi, Switzerland) at $40^{\circ} \mathrm{C}$. Extracts were labeled as PSL-E, PSL-EW, PSL-W, PSS-E, PSS-EW, PSS-W, PSR-E, PSR-EW, PSR-W, PSF-E, PSF-EW and PSF-W, respectively, where $\mathrm{PS}=P$. sarmentosum, $\mathrm{L}=$ leaves, $\mathrm{S}=$ Stem, $\mathrm{R}=$ roots, $\mathrm{F}=$ fruits, $\mathrm{EW}=$ ethanol: water (50: 50), $W=$ water, $E=$ ethanol.

\section{Instrumentation and HPLC conditions}

All experiments were performed using an Agilent Technologies 1260 infinity (USA) HPLC system with UV detector, quaternary pump, online degasser, and column incubator. Separation was done on two different $\mathrm{C}-18$ columns $(250 \times 4.6$ $\mathrm{mm}, 5 \mu \mathrm{m})(\mathrm{A})$ ZORBAX Eclipse Plus PhenylHexyl, C-18 column and (B) ZORBAX Eclipse Plus C-18 made by Agilent Technologies (USA), using an isocratic mobile phase consisting $0.1 \%$ phosphoric acid : acetonitrile : methanol $50: 40$ : 10 , the flow rate was set at $1 \mathrm{ml} / \mathrm{min}$, column temperature was maintained at $30{ }^{\circ} \mathrm{C}$, and detection was performed at $210 \mathrm{~nm}$. Injection volume was $10 \mu \mathrm{L}$ and data acquisition was carried out by Agilent ChemStation software for LC systems.

\section{Preparation of the standard mixture}

A stock solution of a mixture of $\alpha$ - and $\beta$-asarone was prepared at $1 \mathrm{mg} / \mathrm{mL}$ in HPLC grade methanol, and serial dilutions were prepared in the range $0.44-250 \mu \mathrm{g} / \mathrm{mL}$. $P$. sarmentosum extracts were also prepared at $10 \mathrm{mg} / \mathrm{mL}$ in the same solvent and were further diluted to 1 $\mathrm{mg} / \mathrm{mL}$ with methanol. Both, samples and standard stock solution were filtered through 0.45 $\mu \mathrm{m}$ syringe filters.

\section{Method validation}

The proposed method was validated on both columns according to the $\mathrm{ICH}$ guidelines [22]. The following validation characteristics were evaluated: selectivity, linearity, precision, accuracy and the limits of detection and quantification (LOD and LOQ).

\section{Linearity}

Linearity was determined by injecting $10 \mu \mathrm{L}$ of the standard mixture in the concentration range 
$0.448-250 \mu \mathrm{g} / \mathrm{mL}$. The calibration curves were obtained by plotting peak area versus concentration, and linearity (R2) was determined by regression analysis of the calibration graphs.

\section{Selectivity}

The selectivity of method was determined by comparing the retention time of target compounds obtained in the sample extracts with their reference counterparts, and by spiking the extracts with known concentration of the reference compounds.

\section{Precision}

Precision was determined as the coefficient of variation $(\% \mathrm{CV})$ of peak area and retention time. The standard mixture was analyzed at 5 concentrations in the range $7.81-125 \mu \mathrm{g} / \mathrm{mL}$, and the intraday, interday and intermediate precisions were determined $(n=5)$.

\section{Accuracy}

Accuracy was determined as a percentage recovery of $\alpha$ - and $\beta$-asarone at 3.16, 6.25 and $12.5 \mu \mathrm{g} / \mathrm{mL}$ added to the ethanol extract at 1000 $\mu \mathrm{g} / \mathrm{mL}$. The peak area corresponding to the compounds in the ethanol extract (B), the individual reference compounds (C) and their combinations $(A)$ were recorded. The percentage recovery was then calculated using the following formula: \% Recovery $=((A-B) / C) \times 100$. The results are presented average $\pm S D(n=3)$.

\section{Limits of detection (LOD) and of quantification (LOQ)}

The LOD and LOQ were calculated from the slope and standard deviation method as in Eqs 1 and 2.

$$
\begin{aligned}
& \mathrm{LOD}=(3.3 \times \delta) / \mathrm{S} \\
& \mathrm{LOQ}=(10 \times \delta) / \mathrm{S} .
\end{aligned}
$$

Where $\delta=$ is the standard deviation of the $Y$ intercept of the linear regression equation. $S=$ the slope of the linear regression equation [22].

\section{Determination of $\alpha$ - and $\beta$-asarone concentration in $P$. sarmentosum extracts}

Three different extracts from 4 parts of $P$. sarmentosum were analyzed for asarone contents (Figures 2 and 3). Concentrations of $\alpha$ and $\beta$-asarones were calculated by applying the linear regression equations of the reference compounds. The identifications of asarones were done by comparing the retention times to those of standards, as well as adding the individual standard to the samples. $P$. sarmentosum extracts $(10 \mu \mathrm{L})$ were injected at $1000 \mu \mathrm{g} / \mathrm{mL}$, and the peak areas corresponding to $\alpha$ - and $\beta$ asarone were recorded. The linear regression equations of the standard calibration curves were applied to calculate the concentrations of the marker compounds, and the results are presented as mean \% wt/wt using the formula: \% $\mathrm{wt} / \mathrm{wt}=$ (the found concentration $/ 1000 \mu \mathrm{g} / \mathrm{mL}$ ) $\times$ 100

\section{Statistical analysis}

Statistical calculations were carried out using SPSS 20.0 software package. Independent sample t-test was applied and the differences were considered significant at $p<0.05$.

\section{RESULTS}

It is reported that trans/ $\alpha$ - isomers stays for a longer time in column as compared cis/ $\beta$-isomer [23]. So in the present study, it was observed that with each column the cis/ $\beta$-asarone had a lower retention time than the trans/a-asarone. In terms of column comparison, we found that column A has significantly shorter retention time for the elution of $\alpha$ - and $\beta$-asarone which were $11.89 \pm 0.008 \mathrm{~min}$ and $10.80 \pm 0.004 \mathrm{~min}$ compared to column B $15.11 \pm 0.024 \mathrm{~min}$ and $13.29 \pm 0.018 \mathrm{~min}, \quad$ (Figure 1). The dimethylphenylhexylsilane stationary phase in column $A$ was able to elute the target compounds faster than column B which contained dimethyl-n-octadecylsilane stationary phase. Column B showed better resolution (1.82 $\pm 0.025 \mathrm{~min}$ difference between) of the isomers as compared to column $A(1.10 \pm 0.01 \mathrm{~min}$ difference) which was statistically significant, $p<$ 0.001 . We also found that both columns showed comparable sensitivity, precision and selectivity of the compounds investigated. Column A had higher sensitivity with lower LOD and LOQ compared to column B.

\section{Selectivity}

The selectivity of the method was determined by comparing the retention times of $\alpha$ - and $\beta$ asarone obtained in the sample extracts with those of the reference compounds on both columns. The retention time of $\alpha$ - and $\beta$-asarone was $11.8 \pm 0.002$ and $10.79 \pm 0.021 \mathrm{~min}$ on column A while it was $15.09 \pm 0.01$ and $13.26 \pm$ 0.02 min for column $B$ respectively. 
A

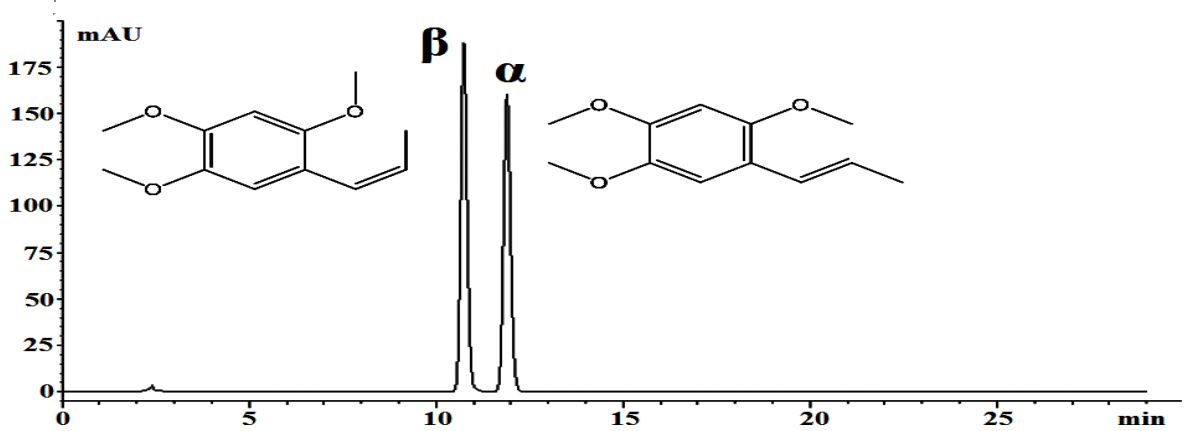

B

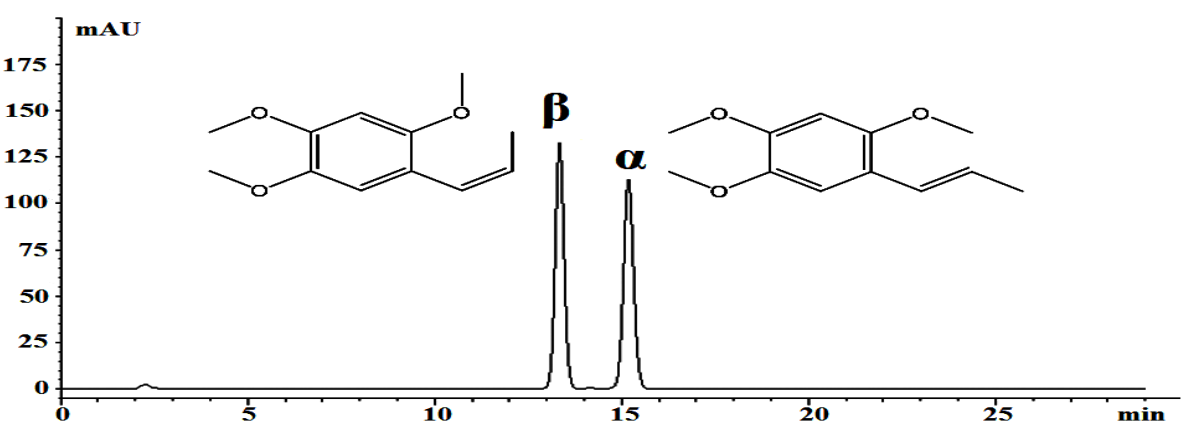

Figure 1: HPLC chromatograms of $\alpha$ - and $\beta$-asarone at $210 \mathrm{~nm}$. A = ZORBAX Eclipse Plus Phenyl-Hexyl C-18 column, $\mathrm{B}=$ ZORBAX Eclipse Plus C-18 column

Their counterparts in $P$. sarmentosum extracts were eluted at $11.81 \pm 0.002$ and $10.8 \pm 0.03 \mathrm{~min}$ on column A while they eluted $15.28 \pm 0.67$ and $13.33 \pm 0.03 \mathrm{~min}$, respectively, on column $\mathrm{B}$. Spiking the extracts with $\alpha$ - and $\beta$-asarone increased the peak areas of the compounds without any shift in the retention times and appearance of extra peaks. This further confirmed the identity of the compounds and the method's selectivity on both columns.

\section{Linearity}

Linearity was presented in terms of the regression coefficient $\left(R^{2}\right)$ of the regression equations of reference compounds $\left(R^{2}\right)$ was $0.999 \pm 0.001$ for both $\alpha$ - and $\beta$-asarone which indicate good linearity of the proposed method using two different columns.

\section{Precision}

The precision was calculated in terms of the \% CV of the retention time and peak area (Table 1 and 2). The $\alpha$ - and $\beta$-asarone were eluted at $11.800 \pm 0.002$ and $10.790 \pm 0.021 \mathrm{~min}$ on column A with $\mathrm{CV}$ of $<0.05 \%$, and $15.09 \pm 0.01$ min and $13.26 \pm 0.02$ min with a $\% \mathrm{CV}$ of $<0.42$ $\%$ on column B, respectively. The \% CV of the peak areas were calculated in the concentration range $7.81-125 \mu \mathrm{g} / \mathrm{mL}$ with an average of < 0.05 and $<0.20 \%$ on columns A and B respectively. These results indicated good reproducibility of retention times and peak areas on both columns.

\section{Accuracy and recovery}

The results are presented as recovery of the reference compounds, viz, 31.25, 62.5, and 125 $\mu \mathrm{g} / \mathrm{mL}$ ranging from $97 \pm 0.50$ and $99 \pm 0.5 \%$ for columns $A$ and $B$, respectively.

\section{LOD and LOQ}

The LOD and LOQ of $\alpha$ - and $\beta$-asarone with column $A$ and $B$ were calculated and presented in Table 2.

\section{$\alpha$ - and $\beta$-asarone in extracts of $P$. sarmentosum}

Asarone contents in the extracts of different parts of $P$. sarmentosum varied between the samples and are shown in Table 3 . The $\alpha$-asarone was found from $0.36-5.14 \%$ in ethanol and $50 \%$ ethanol extracts of $P$. sarmentosum parts and absent in all water extracts. $\beta$-asarone was found in lesser amounts in the ranges from $0.01-0.15$ $\%$ in ethanol and $50 \%$ ethanol extract and was absent in all water extracts of different parts of $P$. sarmentosum.

Trop J Pharm Res, January 2016; 15(1): 160 
Table 1: Precision analysis of $\alpha$ - and $\beta$-asarone using both columns

\begin{tabular}{|c|c|c|c|c|c|c|c|c|c|}
\hline \multicolumn{10}{|c|}{$\alpha$-asarone } \\
\hline Precision & & Column A & & & & Column B & & & \\
\hline \multirow[t]{6}{*}{ Intraday } & $\begin{array}{l}\text { Conc. } \\
(\mu \mathrm{g} / \mathrm{mL})\end{array}$ & $\mathrm{PA}\left(\mathrm{mAU}{ }^{\star} \mathrm{S}\right) \mathrm{AV} \pm \mathrm{SD}$ & $\% \mathbf{C V}$ & RT (min) AV $\pm S D$ & $\% \mathbf{C V}$ & PA (mAU*S) AV $\pm S D$ & $\% \mathbf{C V}$ & RT (min) AV $\pm S D$ & $\% \mathrm{CV}$ \\
\hline & 125 & $8021.0 \pm 1.42$ & 0.02 & $11.89 \pm 0.005$ & 0.04 & $8005.16 \pm 3.10$ & 0.04 & $15.08 \pm 0.01$ & 0.08 \\
\hline & 62.5 & $4236.8 \pm 0.45$ & 0.02 & $11.89 \pm 0.005$ & 0.04 & $4263.42 \pm 2.31$ & 0.05 & $15.09 \pm 0.00$ & 0.03 \\
\hline & 31.25 & $2080.8 \pm 0.84$ & 0.04 & $11.90 \pm 0.007$ & 0.05 & $2160.56 \pm 1.89$ & 0.09 & $15.15 \pm 0.01$ & 0.04 \\
\hline & 15.625 & $1075.8 \pm 1.09$ & 0.10 & $11.89 \pm 0.004$ & 0.03 & $1097.52 \pm 2.78$ & 0.25 & $15.14 \pm 0.01$ & 0.04 \\
\hline & 7.8125 & $542.0 \pm 0.00$ & 0.00 & $11.87 \pm 0.043$ & 0.36 & $568.20 \pm 1.07$ & 0.19 & $15.15 \pm 0.01$ & 0.06 \\
\hline \multirow[t]{5}{*}{ Interday } & 125 & $8022.4 \pm 1.14$ & 0.01 & $11.90 \pm 0.01$ & 0.01 & $7967.56 \pm 1.67$ & 0.02 & $15.09 \pm 0.00$ & 0.02 \\
\hline & 62.5 & $4235.8 \pm 1.09$ & 0.02 & $11.89 \pm 0.02$ & 0.02 & $4263.87 \pm 1.99$ & 0.05 & $15.09 \pm 0.01$ & 0.04 \\
\hline & 31.25 & $2082 \pm 0.70$ & 0.03 & $11.90 \pm 0.03$ & 0.01 & $2138.23 \pm 2.49$ & 0.12 & $15.09 \pm 0.01$ & 0.07 \\
\hline & 15.625 & $1075.2 \pm 0.83$ & 0.07 & $11.90 \pm 0.01$ & 0.01 & $1097.75 \pm 1.97$ & 0.18 & $15.09 \pm 0.01$ & 0.06 \\
\hline & 7.8125 & $543.8 \pm 0.83$ & 0.15 & $11.89 \pm 0.03$ & 0.00 & $563.98 \pm 3.42$ & 0.61 & $15.09 \pm 0.01$ & 0.05 \\
\hline Inter- & 125 & $8022.4 \pm 1.14$ & 0.01 & $11.90 \pm 0.09$ & 0.02 & $7986.36 \pm 1.00$ & 0.01 & $15.09 \pm 0.01$ & 0.04 \\
\hline \multirow{4}{*}{ mediate } & 62.5 & $8021.7 \pm 0.99$ & 0.01 & $11.89 \pm 0.002$ & 0.01 & $4263.65 \pm 0.22$ & 0.01 & $15.09 \pm 0.00$ & 0.01 \\
\hline & 31.25 & $4236.3 \pm 0.71$ & 0.01 & $11.89 \pm 0.001$ & 0.00 & $2149.39 \pm 0.42$ & 0.02 & $15.12 \pm 0.00$ & 0.02 \\
\hline & 15.625 & $2081.4 \pm 0.85$ & 0.04 & $11.90 \pm 0$ & 0.01 & $1097.64 \pm 0.58$ & 0.05 & $15.11 \pm 0.00$ & 0.02 \\
\hline & 7.8125 & $1075.5 \pm 0.42$ & 0.03 & $11.89 \pm 0.001$ & 0.11 & $566.09 \pm 1.66$ & 0.29 & $15.12 \pm 0.00$ & 0.00 \\
\hline \multicolumn{10}{|c|}{$\beta$-asarone } \\
\hline \multirow[t]{6}{*}{ Intraday } & 125 & $8389.6 \pm 1.1$ & 0.01 & $10.79 \pm 0.005$ & 0.05 & $7977.84 \pm 1.71$ & 0.02 & $13.31 \pm 0.00$ & 0.00 \\
\hline & 62.5 & $4485.8 \pm 1.7$ & 0.03 & $10.79 \pm 0.005$ & 0.05 & $4190.78 \pm 2.60$ & 0.06 & $13.31 \pm 0.00$ & 0.00 \\
\hline & 31.25 & $2243.6 \pm 1.1$ & 0.05 & $10.79 \pm 0.008$ & 0.08 & $2193.30 \pm 3.99$ & 0.18 & $13.30 \pm 0.01$ & 0.04 \\
\hline & 15.625 & $1237.8 \pm 1.4$ & 0.13 & $10.79 \pm 0.005$ & 0.05 & $1116.04 \pm 2.76$ & 0.25 & $13.30 \pm 0.00$ & 0.00 \\
\hline & 7.8125 & $646.2 \pm 0.83$ & 0.12 & $10.80 \pm 0.004$ & 0.04 & $7977.84 \pm 1.71$ & 0.02 & $13.31 \pm 0.00$ & 0.00 \\
\hline & 125 & $8389.8 \pm 1.2$ & 0.02 & $10.8 \pm 0.00$ & 0.06 & $8018.86 \pm 3.25$ & 0.04 & $13.27 \pm 0.02$ & 0.18 \\
\hline \multirow[t]{4}{*}{ Interday } & 62.5 & $4487.4 \pm 1.5$ & 0.03 & $10.796 \pm 0.00$ & 0.05 & $4198.37 \pm 3.82$ & 0.09 & $13.27 \pm 0.02$ & 0.18 \\
\hline & 31.25 & $2243.6 \pm 1.1$ & 0.05 & $10.798 \pm 0.00$ & 0.07 & $2196.84 \pm 3.31$ & 0.15 & $13.27 \pm 0.02$ & 0.18 \\
\hline & 15.625 & $1235.4 \pm 1.3$ & 0.10 & $10.796 \pm 0.00$ & 0.05 & $1115.91 \pm 2.46$ & 0.22 & $13.26 \pm 0.02$ & 0.18 \\
\hline & 7.8125 & $647 \pm 0.00$ & 0.00 & $10.8025 \pm 0.00$ & 0.04 & $581.46 \pm 2.36$ & 0.41 & $13.26 \pm 0.02$ & 0.18 \\
\hline Inter- & 125 & $8389.7 \pm 0.14$ & 0.00 & $10.797 \pm 0.00$ & 0.03 & $7998.35 \pm 1.09$ & 0.01 & $13.29 \pm 0.02$ & 0.13 \\
\hline \multirow[t]{4}{*}{ mediate } & 62.5 & $4486.6 \pm 1.13$ & 0.02 & $10.796 \pm 0.00$ & 0.00 & $4194.58 \pm 0.86$ & 0.02 & $13.29 \pm 0.02$ & 0.13 \\
\hline & 31.25 & $2243.6 \pm 0.00$ & 0.00 & $10.797 \pm 0.00$ & 0.01 & $2195.07 \pm 0.48$ & 0.02 & $13.29 \pm 0.01$ & 0.10 \\
\hline & 15.625 & $1236.6 \pm 1.69$ & 0.13 & $10.795 \pm 0.00$ & 0.01 & $1115.98 \pm 0.21$ & 0.02 & $13.28 \pm 0.02$ & 0.12 \\
\hline & 7.8125 & $646.6 \pm 0.56$ & 0.08 & $10.8022 \pm 0.00$ & 0.00 & $581.89 \pm 0.06$ & 0.01 & $13.28 \pm 0.01$ & 0.09 \\
\hline
\end{tabular}


Table 2: Summary of $\alpha$ - and $\beta$-asarone calibration data on column $A$ and B. The regression equation is $(y=a x+b)$, where $(a)$ is the slope and $(b)$ is the $y$ intercept

\begin{tabular}{|c|c|c|c|c|c|c|c|c|}
\hline \multicolumn{9}{|c|}{$\alpha$-Asarone } \\
\hline \multicolumn{2}{|c|}{ Column A } & \multicolumn{7}{|c|}{ Column B } \\
\hline Precision & $a(\mathrm{AV} \pm \mathrm{SD})$ & $b(\mathrm{AV} \pm \mathrm{SD})$ & $\begin{array}{l}\operatorname{LOD}(\mu \mathrm{g} / \mathrm{mL}) \\
(\mathrm{AV} \pm \mathrm{SD})\end{array}$ & $\begin{array}{l}\mathrm{LOQ}(\mu \mathrm{g} / \mathrm{mL}) \\
(\mathrm{AV} \pm \mathrm{SD})\end{array}$ & $a(\mathrm{AV} \pm \mathrm{SD})$ & $b(\mathrm{AV} \pm \mathrm{SD})$ & $\begin{array}{l}\text { LOD } \\
(\mu \mathrm{g} / \mathrm{mL}) \\
(\mathrm{AV} \pm \mathrm{SD})\end{array}$ & $\begin{array}{l}\mathrm{LOQ}(\mu \mathrm{g} / \mathrm{mL}) \\
(\mathrm{AV} \pm \mathrm{SD})\end{array}$ \\
\hline Intraday & $63.928 \pm 0.01$ & $94.712 \pm 0.63$ & $0.032 \pm 0.00$ & $0.099 \pm 0.00$ & $63.558 \pm 0.13$ & $142.06 \pm 4.25$ & $0.22 \pm 0.000$ & $0.67 \pm 0.001$ \\
\hline Interday & $63.928 \pm 0.01$ & $95.170 \pm 0.66$ & $0.034 \pm 0.00$ & $0.10 \pm 0.00$ & $62.926 \pm 0.87$ & $143.54 \pm 0.00$ & $0.30 \pm 0.001$ & $0.90 \pm 0.010$ \\
\hline \multicolumn{9}{|c|}{$\beta$-asarone } \\
\hline Intraday & $66.058 \pm 0.01$ & $200.64 \pm 0.54$ & $0.027 \pm 0.00$ & $0.081 \pm 0.00$ & $62.950 \pm 0.03$ & $162.60 \pm 2.86$ & $\begin{array}{l}0.09 \pm \\
0.001\end{array}$ & $0.27 \pm 0.004$ \\
\hline Interday & $66.066 \pm 0.01$ & $200.24 \pm 0.68$ & $0.034 \pm 0.01$ & $0.103 \pm 0.00$ & $63.252 \pm 0.12$ & $155.64 \pm 0.01$ & $\begin{array}{l}0.19 \pm \\
0.001\end{array}$ & $0.59 \pm 0.001$ \\
\hline
\end{tabular}

Table 3: Summary of $\alpha$ - and $\beta$-asarone concentration in three extracts of different parts of $P$. sarmentosum

\begin{tabular}{|c|c|c|c|c|c|c|c|c|}
\hline \multirow[b]{2}{*}{ Samples } & \multicolumn{4}{|c|}{ Column A } & \multicolumn{4}{|c|}{ Column B } \\
\hline & RT (min) & $\alpha$-asarone $(\% \pm \mathrm{SD})$ & RT (min) & $\beta$-asarone $(\% \pm \mathrm{SD})$ & RT (min) & $\alpha$-asarone $(\% \pm \mathrm{SD})$ & RT (min) & $\beta$-asarone $(\% \pm \mathrm{SD})$ \\
\hline PSL-E & 11.95 & $1.56 \pm 0.001$ & 10.78 & $0.08 \pm 0.001$ & 15.16 & $1.53 \pm 0.001$ & 13.32 & $0.07 \pm 0.003$ \\
\hline PSL-EW & 11.95 & $0.85 \pm 0.001$ & 10.78 & $0.09 \pm 0.003$ & 15.15 & $0.83 \pm 0.001$ & 13.32 & $0.09 \pm 0.002$ \\
\hline PSL-W & $\mathrm{N} / \mathrm{D}$ & $\mathrm{N} / \mathrm{D}$ & $\mathrm{N} / \mathrm{D}$ & N/D & N/D & $\mathrm{N} / \mathrm{D}$ & N/D & $N / D$ \\
\hline PSS-E & 11.92 & $0.42 \pm 0.00$ & $\mathrm{~N} / \mathrm{D}$ & $\mathrm{N} / \mathrm{D}$ & 15.20 & $0.40 \pm 0.002$ & $\mathrm{~N} / \mathrm{D}$ & $\mathrm{N} / \mathrm{D}$ \\
\hline PSS-EW & 11.93 & $0.38 \pm 0.002$ & $\mathrm{~N} / \mathrm{D}$ & $\mathrm{N} / \mathrm{D}$ & 15.20 & $0.36 \pm 0.001$ & $N / D$ & $\mathrm{~N} / \mathrm{D}$ \\
\hline PSS-W & $N / D$ & $N / D$ & $N / D$ & $\mathrm{~N} / \mathrm{D}$ & $N / D$ & $\mathrm{~N} / \mathrm{D}$ & $\mathrm{N} / \mathrm{D}$ & $\mathrm{N} / \mathrm{D}$ \\
\hline PSR-E & 11.92 & $5.14 \pm 0.001$ & 10.78 & $0.15 \pm 0.001$ & 15.10 & $5.11 \pm 0.003$ & 13.27 & $0.14 \pm 0.000$ \\
\hline PSR-EW & 11.96 & $1.14 \pm 0.002$ & 10.8 & $0.01 \pm 0.001$ & 15.12 & $1.13 \pm 0.001$ & 13.28 & $0.01 \pm 0.001$ \\
\hline PSR-W & $N / D$ & $\mathrm{~N} / \mathrm{D}$ & $\mathrm{N} / \mathrm{D}$ & $N / D$ & N/D & $\mathrm{N} / \mathrm{D}$ & $N / D$ & $N / D$ \\
\hline PSF-E & 11.96 & $3.84 \pm 0.001$ & 10.8 & $0.11 \pm 0.001$ & 15.13 & $3.83 \pm 0.01$ & 13.36 & $0.12 \pm 0.000$ \\
\hline PSF-EW & 11.96 & $3.75 \pm 0.001$ & 10.8 & $0.11 \pm 0.001$ & 15.16 & $3.70 \pm 0.001$ & 13.36 & $0.10 \pm 0.000$ \\
\hline PSF-W & $N / D$ & $\mathrm{~N} / \mathrm{D}$ & $N / D$ & $\mathrm{~N} / \mathrm{D}$ & $N / D$ & $\mathrm{~N} / \mathrm{D}$ & $N / D$ & $\mathrm{~N} / \mathrm{D}$ \\
\hline
\end{tabular}



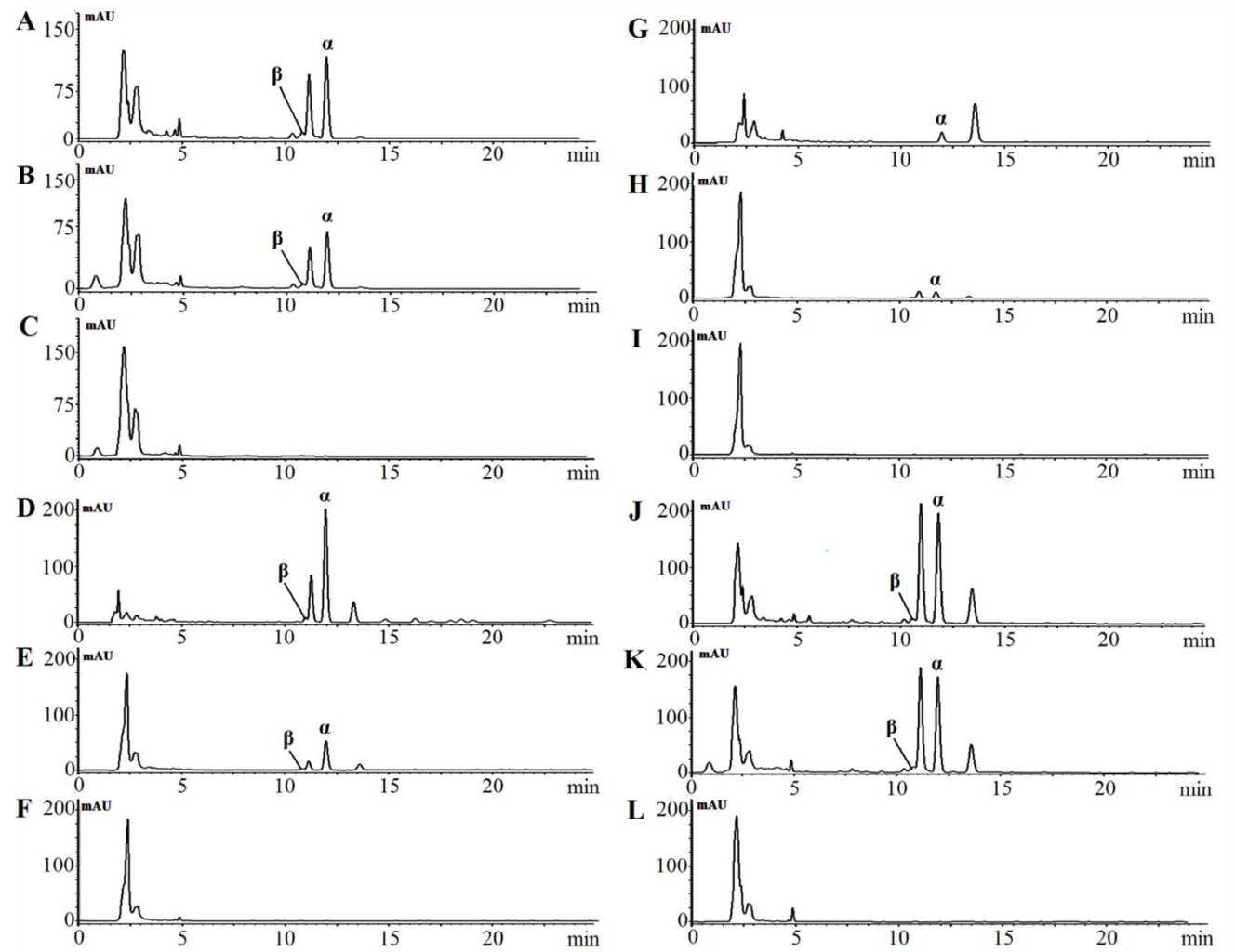

Figure 2: HPLC chromatograms of $\alpha$ - and $\beta$-asarone and $P$. sarmentosum extracts at $210 \mathrm{~nm}$ on ZORBAX Eclipse Plus Phenyl-Hexyl C-18 column. A = PSL-E, B = PSL-EW, C = PSL-W, D = PSR-E, E = PSR-EW, F = PSR-W, G = PSS-E, $H=P S S-E W, I=P S S-W, J=P S F-E, K=P S F-E W$ and $L=P S F-W$

A

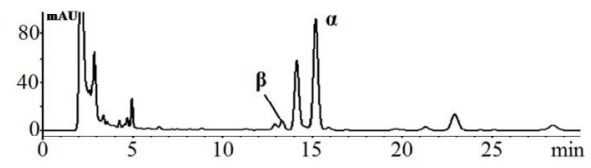

B

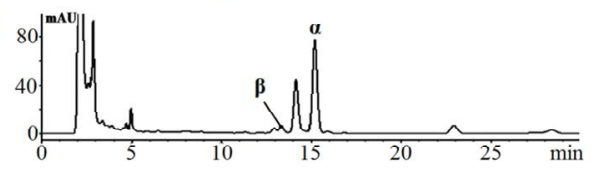

$\mathrm{C}$
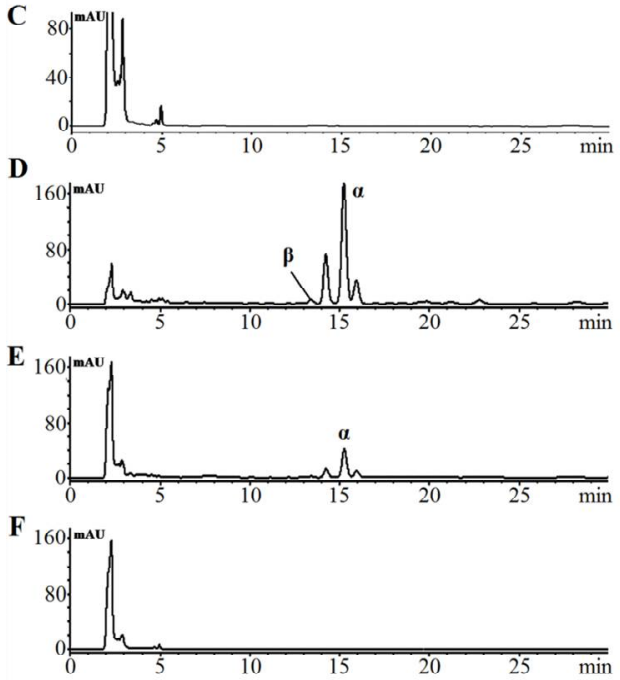

G

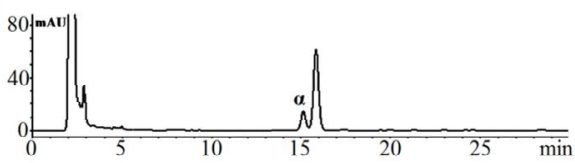

$\mathbf{H}$
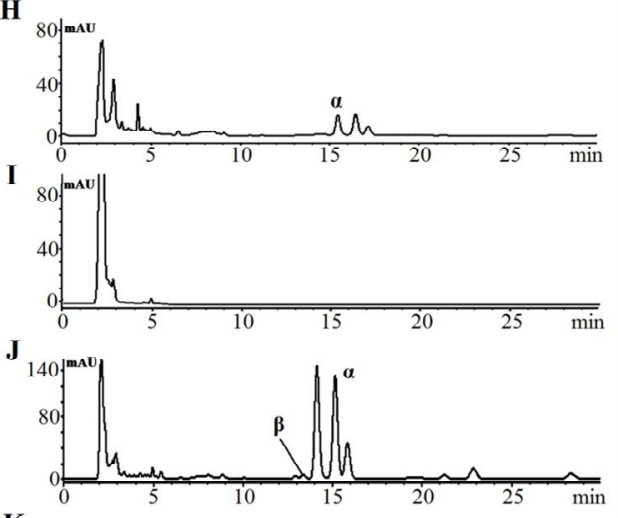

$\mathbf{K}$

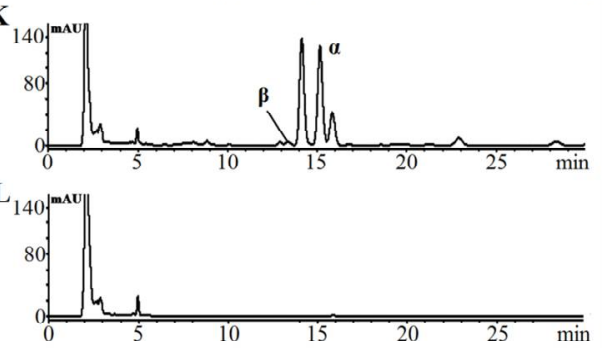

Figure 3: HPLC chromatograms of $\alpha$ - and $\beta$-asarone and $P$. sarmentosum extracts at $210 \mathrm{~nm}$ on ZORBAX Eclipse Plus C-18 column. A = PSL-E, B = PSL-EW, C = PSL-W, D = PSR-E, E = PSR-EW, F = PSR-W, G = PSS-E, $H=P S S-E W, I=P S S-W, J=P S F-E, K=P S F-E W$ and $L=P S F-W$ 


\section{DISCUSSION}

For a long time, $P$. sarmentosum has been used as herbal remedy and food supplement, thus reliable procedures are needed for the quantitative analysis of its phytochemical constituents. In this study, $P$. sarmentosum extracts are analysed for their content of $\alpha$ - and $\beta$-asarone. Both $\alpha$ - and $\beta$-asarone are phenylpropanoids which have been reported to have cytotoxic, genotoxic, carcinogenic, psychoactive effects in both in vitro and in vivo models $[18,21]$.

Based on the HPLC data, $\alpha$-asarone is present as the major isomer in $P$. sarmentosum extracts compared to $\beta$-asarone. This study showed that in different parts of $P$. sarmentosum the concentration of $\alpha$ - and $\beta$-asarone were different and also varied between the extraction methods.

The importance of measuring asarone in $P$. sarmentosum is to determine the best extraction method in order to produce a safer extract which is free from asarone or produce extract with asarone concentration within acceptable limit set by the food regulation bodies, i.e., $115 \mu \mathrm{g} / \mathrm{day}$ [20].

One case study on Acorus calamus herbal preparation which contained asarone has produced side effects such as tachycardia, dizziness, tremor, irregular breathing, pallor, anxiety, nausea and vomiting [24]. From this analysis, we found that water extracts of $P$. sarmentosum are free from asarones and practically safe for consumption.

\section{CONCLUSION}

The developed HPLC method is simple, rapid and compatible with two different $\mathrm{C}-18$ columns for the quantification of $\alpha$ - and $\beta$-asarone in $P$. sarmentosum extracts.

The analysis of different extracts of various parts of the plant showed variations in asarone content. The method is promising for determining asarone isomers in medicinal herbs.

\section{ACKNOWLEDGEMENT}

The authors would like to acknowledge Ministry of Agriculture and the agro-based industry, both in Malaysia (Grant no. 304/PFARMASI/650653) for funding this research as well as Universiti Sains Malaysia for providing the facilities and equipment for the study.

\section{REFERENCES}

1. Wiart C. Medicinal Plants of Asia and The Pacific. Florida, USA: CRC Press; 2006; $p 336$.

2. Peungvicha $P$, Thirawarapan SS, Temsiririrkkul $R$, Watanabe H, Prasain JK, Kadota S. Hypoglycemic Effect of The Water Extract of Piper sarmentosum in rats. J Ethnopharmacol 1998; 60: 27-32.

3. Sawangjiaroen $N$, Sawangjiaroen $K$, Poonpanang $P$. Effects of Piper longum fruit, Piper sarmentosum root and Quercus infectoria nut gall on caecal amoebiasis in mice. J Ethnopharmacol 2004; 91: 357-360.

4. Masuda T, Inazumi A, Yamada Y, Padolina WG, Kikuzaki $H$, Nakatani N. Antimicrobial Phenylpropanoids from Piper sarmentosum. Phytochemistry 1991; 30: 32273228.

5. Ridtitid W, Rattanaprom W, Thaina P, Chittrakarn $S$, Sunbhanich M. Neuromuscular blocking activity of methanolic extract of Piper sarmentosum leaves in the rat phrenic nerve-hemidiaphragm preparation. $J$ Ethnopharmacol 1998; 61: 135-142.

6. Rahman NNNA, Furuta T, Kojima S, Takane K, Mohd MA. Antimalarial Activity of Extracts of Malaysian Medicinal Plants. J Ethnopharmacol 1999; 64: 249-254.

7. Hutadilok NT, Chaiyamutti $P$, Panthong $K$, Mahabusarakam W, Rukachaisirikul V. Antioxidative and Free Radical Scavenging Activities of Some Plants Used in Thai Folk Medicine. Pharm Biol 2006; 44: 221 228.

8. Rukachaisirikul $T$, Siriwattanakit $P$, Sukcharoenphol $K$, Wongvein $C$, Ruttanaweang $P$, Wongwattanavuch $P$, Suksamrarn A. Chemical constituents and bioactivity of Piper sarmentosum. J Ethnopharmacol 2004; 93: 173176.

9. Ariffin $S H Z$, Wan Omar WHH, Ariffin ZZ, Safian MF, Senafi $S$, Megat Abdul Wahab $R$. Intrinsic anticarcinogenic effects of Piper sarmentosum ethanolic extract on a human hepatoma cell line. Cancer Cell Int 2009; 9: 1-9.

10. Hussain K, Ismail Z, Sadikun A, Ibrahim P, Malik A. Invitro Antiangiogenesis Activity of Standardized Extracts of Piper sarmentosum Roxb. J Riset Kimia 2009; 1: 146150.

11. Parmar VS, Jain SC, Bisht KS, Jain R, Taneja $P$, Jha $A$, Tyagi OD, Prasad AK, Wengel J, Olsen CE, Boll, PM. Phytochemistry of the genus Piper. Phytochem 1997; 46: 597-673.

12. Subramaniam V, Adenan MI, Ahmad AR, Sahdan $R$. Natural Antioxidants: Piper sarmentosum (Kadok) and Morinda elliptica (Mengkudu). Malays J Nutr 2003; 9: 41-51.

13. Chan P, Soon-II K, Young-Joon A. Insecticidal activity of asarones identified in Acorus gramineus rhizome against three coleopteran stored-product insects. J Stored Prod Res 2003; 39: 333-342.

14. Cho J, Kim YH, Kong J-Y, Yang CH, Park CG. Protection of cultured rat cortical neurons from excitotoxicity by asarone, a major essential oil component in the

Trop J Pharm Res, January 2016; 15(1): 164 
rhizomes of Acorus gramineus. Life Sci 2002; 71: 591 599.

15. Wiseman RW, Miller EC, Miller JA, Liem A. Structureactivity studies of the hepatocarcinogenicities of alkenylbenzene derivatives related to estragole and safrole on administration to preweanling male C57BL/6J x C3H/HeJ F1 mice. Cancer Res 1987; 47: 2275-2283.

16. Hasheminejad G, Caldwell J. Genotoxicity of the alkenylbenzenes $\alpha$ - and $\beta$-asarone, myristicin and elemicin as determined by the UDS assay in cultured rat hepatocytes. Food Chem Toxicol 1994; 32: 223-231.

17. Schmidt GH, Streloke M. Effect of Acorus calamus (L.) (Araceae) oil and its main compound $\beta$-asarone on Prostephanus truncatus (Horn) (Coleoptera: Bostrichidae). J Stored Prod Res 1994; 30: 227-235.

18. Unger P, Melzig MF. Comparative Study of the Cytotoxicity and Genotoxicity of Alpha- and BetaAsarone. Sci Pharm 2012; 80: 663-668.

19. Commisssion E. Opinion of the Scientific Committee on Food on the presence of $\beta$-asarone in flavourings and other food ingredients with flavouring properties, 2002 [cited 18 June 2014]. Available from: http://europa.eu.int/comm/food/fs/sc/scf/index_en.html

20. Agency EM. Public statement on the use of herbal medicinal products containing asarone. London; 2005.

21. WHO. Toxicological Evaluation of Certain Food Additives - Beta-Asarone, 1981 [cited 19 June 2014]. Available from:

www.inchem.org/documents/jecfa/jecmono/v16je04.htm

22. ICH. Guidance for Industry, Q2B: Validation of Analytical Procedures: Methodology. USA: International Conference of Harmonisation; 1997.

23. Baxter RM, Fan MC, Kandel SL. Cis-Trans Trans isomers of asarone, their liquid-gas chromatographic behavior and that of certain other propenylphenolethers. Can J Chem 1962; 40: 151-157.

24. Zuba D, Byrska B. Alpha- and beta-asarone in herbal medicinal products. A case study. Forensic Sci Int 2012; 223: 5-9. 